\title{
Demography, breeding success and effects of nest type in artificial colonies of Red-footed Falcons and allies
}

\author{
László Kotymán ${ }^{1}$, Szabolcs SolT², Éva Horváth ${ }^{2}$, \\ Péter Palatitz ${ }^{2} \&$ Péter Fehérvári ${ }^{3 *}$
}

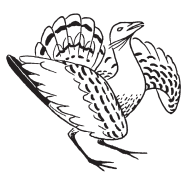

László Kotymán, Szabolcs Solt, Éva Horváth, Péter Palatitz \& Péter Fehérvári 2015. Demography, breeding success and effects of nest type in artificial colonies of Red-footed Falcons and allies. - Ornis Hungarica 23(1): 1-21. cial breeding platforms, nest-boxes or man-made twig nests often present solutions with remarkable results, however long-term sustainability of these populations remains to be resolved. Furthermore, the question whether the inference of results of studies conducted on birds breeding in artificial breeding sites can be generalized to other populations, still remains open. Here we present the history, and the results of a 20 year old (1995-2015) nest-box programme initiated to increase potential breeding possibilities of Red-footed Falcons in an area, where nest-site shortage was a severe limiting factor. We show how various other species (Jackdaws, Kestrels and Long-eared Owls) have utilized these resources, and present descriptive statistics on their reproductive performance. Analysing the data of a total of 1432 breeding attempts, we show that Red-footed Falcons have similar clutch sizes, and nesting success (i.e. ratio of nests with at least on fledgling), however fledging success (ratio of the number of eggs/ fledged nestlings) was different in artificial nest-boxes. When we excluded closed box types from artificial nests, this difference was not apparent. In case of Kestrels ( $\mathrm{n}=1626$ breeding attempts) clutch size was significantly higher in artificial nests, while we found no difference in fledging or nesting success. When only comparing open boxes to natural nests, the difference in clutch size was no longer significant. We also analysed the effect of nest box design on reproductive parameters of the two species using regression trees. Inter annual effects were the most important in shaping clutch size and fledging rate of both falcon species, however we also found nest-box design effects, but only in Red-footed Falcons. In years when mean clutch size was high, these birds had lower clutch size in an older, darker nest-box type compared to an alternative design, and to open boxes. However, fledging rate in the same years was lower for both open boxes and older nest-boxes. We conclude that artificial colonies are an important and successful tool in Red-footed Falcon conservation, and that the breeding parameters measured in artificial colonies depend on nest-box design. We present correlative evidence that closed boxes have a significant positive species specific effect on reproduction, probably due to their protection against weather. We also show that birds may have a preference for a certain nest-box design, and that the breeding success in the less favoured box type may be similar to that in open nests. We recommend that future studies incorporate nest-type and nest-box design effects in all comparisons made on reproductive performance in case of Red-footed Falcons and Kestrels.

Keywords: Falco vespertinus, Falco tinnunculus, Asio otus, Corvus monedula, nest-box, fledging success, clutch size, population trend, colony

Összefoglalás A fészkelőhelyek hiánya fontos limitáló tényezője lehet egyes madárfajok előfordulásának. Mesterséges fészkekkel, fészekodúkkal, költőládákkal vagy müfészkek kihelyezésével ezt a hiányt lehet pótolni, de az állományok hosszú távú fennmaradása az ilyen, ember által kialakított fészkelőhelyeken erősen beavatkozás-függő, önmagában tartósan nem biztosított. További probléma, hogy nem tisztázott, mennyire lehet az ilyen rendszerekben végzett kutatások eredményeit általánosítani természetes fészkekben költő állományokra. Ebben a vizsgálatban bemutatjuk egy 20 éves (1995-2014) telepes költőláda program történetét és eredményeit, amit azzal a céllal kezdtünk el, hogy fészkelőhelyet teremtsünk a kék vércsék számára egy olyan területen, ahol a költőhelyek hiánya súlyos limitáló tényező volt. Bemutatjuk továbbá, hogy az általunk kihelyezett költőládákat hogyan hasznosítják más, nem feltétlenül koloniális madárfajok (vörös vércse, csóka és erdei fülesbagoly), és leíró statisztikákat közlünk a költési eredményeikröl. 


\begin{abstract}
A kék vércsék esetében 1432 költési kísérletet elemezve azt találtuk, hogy sem a fészekaljméret, sem a költéssiker nem különbözik a természetes és a mesterséges fészkek között, azonban a kelési siker alacsonyabb a természetes fészkekben. Ha kihagyjuk a zárt ládákat az elemzésből, ez a különbség nem kimutatható. Vörös vércsék esetében 1626 költési kísérlet elemezve a fészekalj méret szignifikánsan magasabb a költőládákban, de a fészkelési sikeresség és a kirepülési siker nem tér el. Ha kihagyjuk a zárt ládákat az elemzésből, ez a különbség szintén eltűnik. A különböző költőláda típusokban a költési paramétereket döntési fákkal elemeztük. Mindkét vércse fajnál az év hatása a legmeghatározóbb a költési paraméterek formálásában, azonban a költőláda típusoknak szignifikáns hatása volt kék vércsék esetén. A magas átlagos fészekalj méretú években a madarak átlagosan kevesebb tojást raktak egy régebbi, zártabb és sötétebb költőláda típusban, mint a többi ládatípusba. A repítési siker ezekben a jó években mind a régebbi költöláda típusban, mind a nyitott müfészkekben alacsonyabb volt, mint az új kisebb és világosabb zárt ládákban. Korrelációs eredményeink szerint létezik fajspecifikus ládatípus preferencia. Kék vércséknél a zárt ládákban mért magasabb reprodukciós siker feltehetően a tetővel rendelkező ládák zord időjárási körülmények ellen való védelmét tükrözi. Javasoljuk, hogy a későbbi vizsgálatok ne csak a fészkek típusát (természetes, mesterséges), de a mesterséges fészkek esetében a láda típusát is vegyék figyelembe.
\end{abstract}

Kulcsszavak: Falco vespertinus, Falco tinnunculus, Asio otus, Corvus monedula, költöláda, költőodú, költési siker, fészekalj méret, kolónia

${ }^{1}$ Körös-Maros National Park Directorate, 5440 Szarvas, Anna liget 1., Hungary

${ }^{2}$ MME/BirdLife Hungary, Red-footed Falcon Conservation Working Group, 1121 Budapest, Költö utca 21., Hungary

${ }^{3}$ Department of Zoology, Hungarian Natural History Museum, 1088 Budapest, Baross utca 13., Hungary, e-mail: peterfehervari@nhmus.hu

*corresponding author

\section{Introduction}

Preserving, managing and exploring the grasslands of the Pannon Biogeographic region is one of the top priorities of Hungarian nature conservation (Báldi et al. 2005). River management and the intensification of agricultural practices of the past 150 years all contributed to the drastic loss of grasslands in the region. Today, Hungary holds the third largest proportion of agricultural land in the EU (Donald et al. 2002). Conservation of grassland type habitats (or so called 'puszta') entails two general approaches, 1) management of landscape level habitat composition and quality through regulations and subsidies (Ángyán et al. 2002) and 2) active, often species or plant association specific conservation measures (e.g. Fehérvári et al. 2012). In the latter case, measures may include habitat reconstruction, eradication of invasive species and supplementing breeding possibilities like nesting islands, artificial twig nests or nest-boxes. For instance, two emblematic species, the Roller (Coracias garrulus) and the Red-footed Falcon (Falco vesperti$n u s)$ typically suffer from shortage of nesting opportunities in Hungary (Bagyura \& Palatitz 2004, Fehérvári et al. 2009, Palatitz et al. 2009, Kiss et al. 2014). The meticulous nest-box programs of the past decades had shifted the majority of breeding pairs of these two species to artificial nesting sites. Red-footed Falcons occupy naturally occurring breeding possibilities like nests built by other species. In Hungary, species that build adequate nests for the falcons are of the genus Corvus, typically Rooks (Corvus frugilegus), Hooded Crows (Corvus corone cornix) and Magpies (Pica pica). In the 1940s, the estimated 2000-2500 pairs of Red-footed Falcons predominantly used rookeries. However, due to a direct corvid specific poisoning protocol, and presumably due to large scale changes in land use, and the collapse of animal husbandry, approximately $90 \%$ of previously available rookeries were 
either demolished or have shifted location to unsuitable habitats for Red-footed Falcons (Fehérvári et al. 2009). By 2006 the estimated breeding population was a below 600 pairs (Palatitz et al. 2015). An international conservation program initiated in 2006 with the primary objective to halt this tendency succeeded in increasing the number of breeding pairs, primarily through provisioning over 3500 nest-boxes (LIFE05/ NAT/HU/122, see www.falcoproject.eu). Today approx. two-thirds of Red-footed Falcon pairs breed in man-made structures in Hungary (Palatitz et al. 2015). Provisioning artificial breeding structures for these falcons has a long history in the Carpathian Basin, the first records of nest-baskets used date back to the first decade of the $20^{\text {th }}$ century (Csörgey 1908). Since then a series of local and/or small scale programs built up valuable experience, that aided the success of the countrywide program (Bagyura \& Palatitz 2004). For instance, in 1989 the Csongrád County local group of MME/ BirdLife Hungary started an artificial nest program at three separate locations (Csanádi-puszták, Cserebökényi-puszták and Baksi-puszta). There was no considerable large breeding population of Red-footed Falcons in the County in the past 60-70 years (Keve \& Szijj 1957, Sterbetz 1959, 1975), only a single larger colony (70 pairs) was reported from Baksi-puszta in the 1960s (Molnár \& Tajti 2007). The neighbouring Békés County held a total of 550 pairs in 13 colonies in 1990, however this population decreased by $50 \%$ in the following five years (Tóth 1995). By the early 2000s, the majority of the remaining pairs also disappeared (Bagyura \& Palatitz 2004). Despite the relative low number of breeding birds in the region, the occupancy rate of the artificial nests and open nest-boxes was surprisingly high (Vajda 1992, Molnár 2000). This program was followed in the Vásárhelyi-puszta in 1995 and still continuous to date, resulting in one of the densest Red-footed Falcon breeding site within the EU (Palatitz et al. 2009). Despite the deliberate aim of colonies to increase the number of Red-footed Falcon breeding pairs, various other species (e.g. Kestrel - Falco tinnunculus, Jackdaw - Corvus monedula, Long-eared Owls Asio otus) are also taking advantage of the nesting sites (Kotymán 2001). The fact that territorial species like Kestrels use colonial nest-boxes, shows the extreme shortage of nests in a near tree-less landscape.

Although nest-boxes are installed for a wide range of species (Mainwaring 2015), and are especially successful in case of small predatory birds in Europe (Hamerstrom et al. 1973, Fargallo et al. 2001, Franco et al. 2005, Bux et al. 2008, Gottschalk et al. 2011, Catry et al. 2013) and in North America (Bortolotti 1994, Katzner et al. 2005), the effect they have on breeding is still poorly understood (Lambrechts et al. 2012). Particularly difficult is to establish whether the inference of studies carried out on birds breeding in structures deliberately erected for them can be generalized to populations breeding in naturally occurring nest sites. For instance, disentangling nest-type effects from that of the foraging habitats can be challenging, as breeding site provisioning is typically carried out as a conservation tool in areas, where they limit population growth of the focal species (Mainwaring 2015).

In this study we report the used box-types, the temporal patterns of colonization of the four most abundant species (i.e. Red-footed Falcon, Kestrel, Jackdaw and Long-eared Owl) and present descriptive statistics of breeding parameters based on large sample sizes from the Vásárhelyi-puszta nest-box 


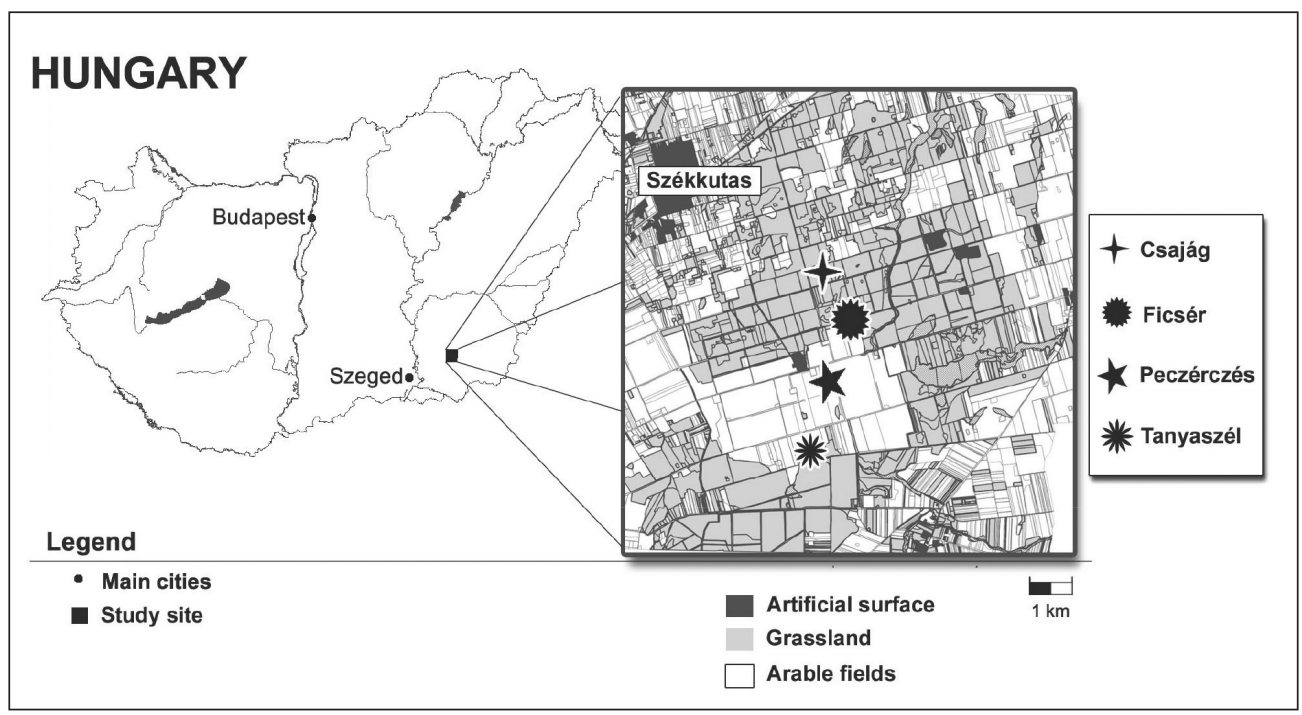

Figure 1. Location of the study site and 4 artificial colonies within. The fifth colony (Tótkutas, see Table 1) is approx. $6 \mathrm{kms}$ southeast from the $10 \times 10 \mathrm{~km}$ study area. The study area was defined primarily to assess habitat structure in previous studies (Palatitz et al. 2011). We also used this area to map solitary pairs breeding in natural nests in the vicinity of the artificial colonies. Recently, two rookeries were established within the loose colony Csajág (see Table 1), the other one is approx. 17 kilometers from this site (outside the study area)

1. ábra A vizsgálati terület és azon belül a 4 mesterséges fészektelep elhelyezkedése. Az ötödik telep (Tótkutas, lásd 1. táblázat) mintegy 6 kilométerre található a kutatási területtől délkeletre. A 10×10 km-es kutatási terület lehatárolást elsősorban korábbi vizsgálatokban használtuk élőhely összetétel meghatározásra (Palatitz et al. 2011), de ebben a vizsgálatban ezt a területet használtuk a természetes fészkekben költő szoliter vércsék feltérképezéséhez. A közelmúltban két vetési varjú telep is létesült: egy a Csajág nevű mesterséges kolóniában (lásd 1. táblázat), és egy másik, mintegy 17 kilométerre innen

program. We also exploit the rare possibility of assessing nest-type effects on breeding performance without marked habitat variability as our data derive from colonies located close to each other (Figure 1).

\section{Materials and Methods}

\section{Study site}

The Vásárhelyi-puszta lies within the municipality borders of Hódmezővásárhely, Békéssámson, Székkutas, Orosháza and Kardoskút (N 46²8'25”, E 20³7'30”).
A total of 8000 ha comprises the area, out of which 5629 ha are part of the Körös-Maros National Park since 1999. The protected area and its surroundings are also $\mathrm{NA}_{\mathrm{A}}$ TURA 2000 sites and constitute the HUKM 10004 SPA. Approximately $60 \%$ of the area is grassland, of which the bulk is utilized as meadows. The composition of livestock grazing extensively in the area is made up of 250-800 cattle, 1800-2500 sheep, 1060 horses. Mowing prior to grazing is carried out on circa $30 \%$ of the grazed areas. The natural type habitats are interspersed with arable fields of variable sizes $(2-150$ ha), where maize, sunflower, various cere- 


\begin{tabular}{|c|c|c|c|c|c|}
\hline $\begin{array}{l}\text { Colony } \\
\text { Name }\end{array}$ & $\begin{array}{l}\text { First breeding } \\
\text { season }\end{array}$ & $\begin{array}{l}\text { Dominant tree } \\
\text { species }\end{array}$ & $\begin{array}{c}\text { Height } \\
(\mathbf{m})\end{array}$ & $\begin{array}{l}\text { Total area } \\
\text { (ha) }\end{array}$ & Description \\
\hline Ficsér & 1995 & Fraxinus excelsior & $7-9$ & 0.6 & Dense, compact colony \\
\hline Csajág & 1996 & $\begin{array}{l}\text { Quercus robur, } \\
\text { Eleganus } \\
\text { angustifolia, } \\
\text { Gleditsia } \\
\text { triacanthos }\end{array}$ & $4-10$ & 10 & $\begin{array}{l}1 \text { dense and } 2 \text { loose } \\
\text { group of nest-boxes } \\
\text { and a rookery }\end{array}$ \\
\hline Peczérczés & 2005 & Ulmus minor & $11-13$ & 0.44 & Dense, compact colony \\
\hline Tanyaszél & 2009 & $\begin{array}{c}\text { Robinia } \\
\text { pseudoacacia }\end{array}$ & $8-15$ & $0.2,0.4$ & $\begin{array}{l}\text { Dense, compact colony in } \\
\text { two distinct group of trees }\end{array}$ \\
\hline Tótkutas & 2013 & $\begin{array}{c}\text { Robinia } \\
\text { pseudoacacia }\end{array}$ & $8-10$ & 1.2 & Dense, compact colony \\
\hline
\end{tabular}

Table 1. Description of the five studied artificial colonies

1. táblázat A vizsgált 5 mesterséges kolónia jellemzői

als, and alfalfa are cultivated typically with intensive agro-technologies. Large scale irrigation is absent from the area. Shallow, endorheic basins in between the arable fields, and grasslands retain temporary saline lakes or marshes. However, total water coverage on the grasslands is not uncommon from early spring to mid-summer. Dirt roads, channels and ditches create a relatively dense network of linear structures in the landscape. Five-six decades ago, the landscape had a sizeable human population with a total of 200 active farms in the area. Currently only 20 active homesteads and 2 livestock farms are present.

The area is plain flat, with an elevation of 86-88.5 m (a.s.1.). Typical soil types of the region are highly alkaline solonchaks, and solonetz. Mean annual sunlit hours are 2000-2050 while temperature 10.4-10.6 ${ }^{\circ} \mathrm{C}$. Daily average maximum temperature in summer is high $\left(34.6-34.8^{\circ} \mathrm{C}\right)$, while annual cumulative precipitation is highly variable $(280-850 \mathrm{~mm})$. Highest average rainfall months are May and June. These two can provide $25 \%$ of the total annual precipitation. The original vegetation of the grass- land remained around the saline lakes and marshes. Typical plant associations of the grasslands are short (Achileo-Festucetum pseudovinae) to medium (Agrostio-Alopecuretum pratensis) vegetation height (Molnár et al. 2012). The most treasured natural value of the area is the diverse bird life present throughout the year. The Kardoskúti Fehér-tó alkaline lake is a Ramsar site, as it is a migratory hotspot for Greater Whitefronted Goose (Anser albifrons), Common Crane (Grus grus), and for various waders (Charadriiformes). Typical breeding species are Yellow Wagtail (Motacilla flava), Skylark (Alauda arvensis), Lesser Grey Shrike (Lanius minor), Marsh Harrier (Circus aeruginosus), Roller, Avocet (Recurvirostra avosetta), Great White Egret (Casmerodius alba), White-tailed Eagle (Haliaeetus albicilla) and Imperial Eagle (Aquila heliaca). Most common mammals of the area are the periodically gradating Field Vole (Microtus arvalis), the European Hamster (Cricetus cricetus), Steppe Mouse (Mus spicilegus), Common Hare (Lepus lepus), Roe Deer (Caprimulgus europeus). Typical predators are Red Fox (Vulpes vulpes), Beech Marten 
(Martes foina) and Weasel (Mustella nivalis) (Kotymán L. pers. obs.).

\section{Location of artificial colonies}

Trees that may support nest-boxes are typically present at the location of former farms, homesteads. Altogether we have created 4 larger colonies more or less aligned on the central north-south axis of the area. A total of 5 larger colonies (Table 1), smaller nestbox groups and a handful of solitary nestboxes were interspersed between the larger colonies. In 2014 we drastically increased the number of solitary nest-boxes, distributing them to various distant locations of the area. The number of breeding platforms was gradually increased at each colony, and currently a total of 250-255 artificial breeding sites are available for the birds. The boxes were placed below the canopy, at 3-8 meters typically on the trunk, or one of the larger branches of the trees. Positioning and exposure of the nest boxes varies, the governing rule of decisions was based on tree structure rather than favouring a chosen direction. Intriguingly, we noticed, that if a nest-box is placed in near perpendicular tree fork, the life expectancy of the nest-box grew considerably. Due to the shortage of trees capable of holding a nest-box we placed often placed 2-9 boxes on a single tree.

\section{Nest-box types}

We predominantly used 3 types of nest-boxes during the past 20 years, 1 open plastic box (1. O.B.), and 2 covered wooden boxes (1. C.B. and 2. C.B) (see Figure 2 for detailed dimensions). The open platform was a 20 litre canister sawed in half, and perforated with $1 \mathrm{~cm}$ holes on the sides and the bottom to allow water to flow through. The useful area is $0.1 \mathrm{~m}^{2}$ and the weight is 0.46 $\mathrm{kg}$. Prior to installing these on the trees, we pressed a 5-8 $\mathrm{cm}$ turf block into the platform and formed a nest like cavity. This was the only box type used until 1999 .

We started placing out 1.C.B. type boxes in 2000. This box comprised of $2 \mathrm{~cm}$ thick pine sideboards, the roof cut out from plywood and strengthened with a tin sheet, while the bottom was created from wattle boards. The total weight is a considerable $7.2 \mathrm{kgs}$, and the inner useful area is $0.11 \mathrm{~m}^{2}$ of this box. We also used $1 \mathrm{~cm}$ wide and $12 \mathrm{~cm}$ long metal strips strengthened to the back of the box to help fixing the boxes in place.

Since 2005 we have been using a new closed box type (2.C.B.), which is smaller and lighter compared to the previous version. Here the sideboards and the roof are made from pine, the bottom from either oak (Quercus spp.), or locust-tree (Robinia pseudo-acacia). All boards got fungicide soaking prior to assembly. Fixing the box on the trees is aided by a $50 \mathrm{~cm}$ long pine board screwed on the back of the box. We also glued a $5 \times 10 \mathrm{~cm}$ mirror on the inner surface of the roof to allow assessing the content without having to climb up to the box. The weight of 2.C.B. is $5.3 \mathrm{~kg}$ while the useful inner area is $0.0625 \mathrm{~m}^{2}$. As nest material, we used a $3-5 \mathrm{~cm}$ thick dry grass bedding. In case the nest material comprised from leftover pellets and remains from previous breeding attempts, in general we did not clean them but see (Fehérvári et al. 2015). All nests were numbered on the bottom, side and front, with either visible white oil paint or with chalk. In a few cases we found a couple of successful Red-footed Falcon nesting attempts in closed D-type boxes, Common Buzzard (Buteo buteo) nests and Wood Pigeon (Columba palumbus) nests, however the vast majority of all 


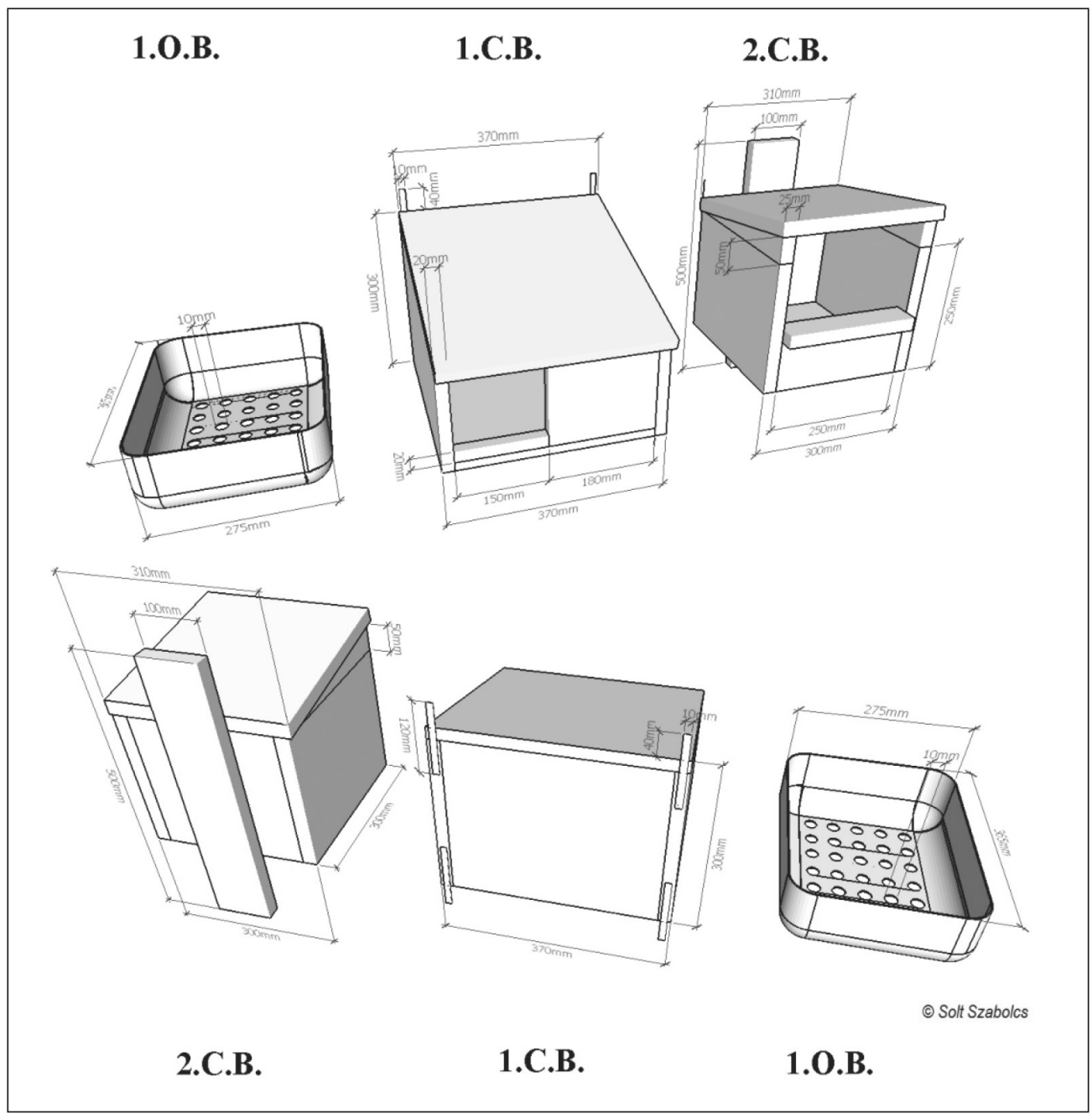

Figure 2. Schematic drawings of the three most commonly used nest-box designs. The open box 1.O.B. was created from 20 litre plastic canisters sawed in half, while the other two are made of wood. All boxes were erected to approx. the same height and with various orientations

2. ábra A három leggyakrabban használt ládatípus tervrajzai. A nyitott láda (1.O.B.) félbevágott 20 literes múanyag marmonkannából, míg a másik két típus fából készült. Az összes ládatípus közel hasonló magasságban és véletlenszerű orientációval került kihelyezésre

breeding attempts occurred in the three nestbox types.

\section{Corvid nests}

Prior to the mid '90s only a dozen or so pairs of Magpies or Hooded Crows bred in the area. However, the local breeding population of both species increased somewhat during the past 20 years. Moreover, the previously completely absent Rooks have also started breeding in 2009 (Horváth et al. 2015). By 2014 over 500 breeding pairs were present in 2 rookeries. 
To monitor Red-footed Falcons not only in artificial colonies, but also in solitary corvid nests, we created the Red-footed Falcon study area in the Vásárhelyi Plain, a 10×10 $\mathrm{km}$ study area centred on the oldest colony (Palatitz et al. 2011), where we mapped all possible breeding attempts.

\section{Assessing breeding performance}

Nest occupancy, clutch size, hatching success and fledging success were monitored throughout the study period by visiting each nest individually. In all cases we used ladders to climb up to the nest, even though from 2006 we had mirrors installed into 2.C.B. type boxes. These mirrors were only used for verification of observations, if deemed necessary. In most cases all nests were visited on the same day, or if conditions hindered this, we visited all nests within a couple of days. In the first two years 2-3 visiting rounds, from 1997-2005, 3-8 rounds, and from 2006, 6-12 rounds were made annually. Red-footed Falcon and Kestrel eggs are practically inseparable based on colour or morphology, therefore to assess the species we collected additional information with spotting-scopes and binoculars. The timing of visits was always adjusted to the individual year's conditions. In general, the first visiting round was made in mid-March and we also carried out necessary maintenance works like refilling nest lining, or refurbishing the boxes in the first round. In April we typically surveyed the boxes 1-2 times, in May at least twice. In June we switched to visiting protocol with 8-14 days in between, while in July the visits were made more frequent with a visit every 7-10 days. In August typically only a handful of late breeders had nestlings, however we followed through with their visits until the last of the fledglings left the boxes. This pattern made it possible to estimate the breeding performance of all species breeding in the boxes, but we were also able to collect data on egg laying date in case of the most common species. We avoided timing the visiting rounds on cold, rainy, or windy days especially during the incubation period. In spring we typically performed rounds around mid-day, while in summer we took advantage of early mornings and late afternoons.

In case of all nests we recorded the species and sex of the birds that left the box upon arrival, the content of the nest-box (species, eggs, nestlings) and all other information that pointed to future occupation of the nest-box (scrapings, missing nest-lining, pellets etc.). We also recorded the type and frequency of identifiable food remains, like carcasses, feathers, skulls. In case we found nestlings, we aged the whole clutch to days, and recorded all abnormalities, like obvious symptoms of illnesses, or general poor condition. Since 2006, 99\% of all Red-footed Falcons were ringed with individually coded colour rings.

We also monitored all breeding attempts that occurred in natural nests within the artificial colonies, in rookeries or at solitary nests with similar intensity. In case of natural nests, however it is not always possible to climb up to the nests, therefore we used a large pole with a mirror attached to the end. The mirror was placed over the nest and the content was checked with binoculars. In this case mid-aged downy nestlings cannot be counted only their presence confirmed. However, once they start growing flight feathers this is easily achievable, thus causing no bias in later analyses. In case of rookeries, we labelled the nests on the trunk of trees to allow identification similar to that 


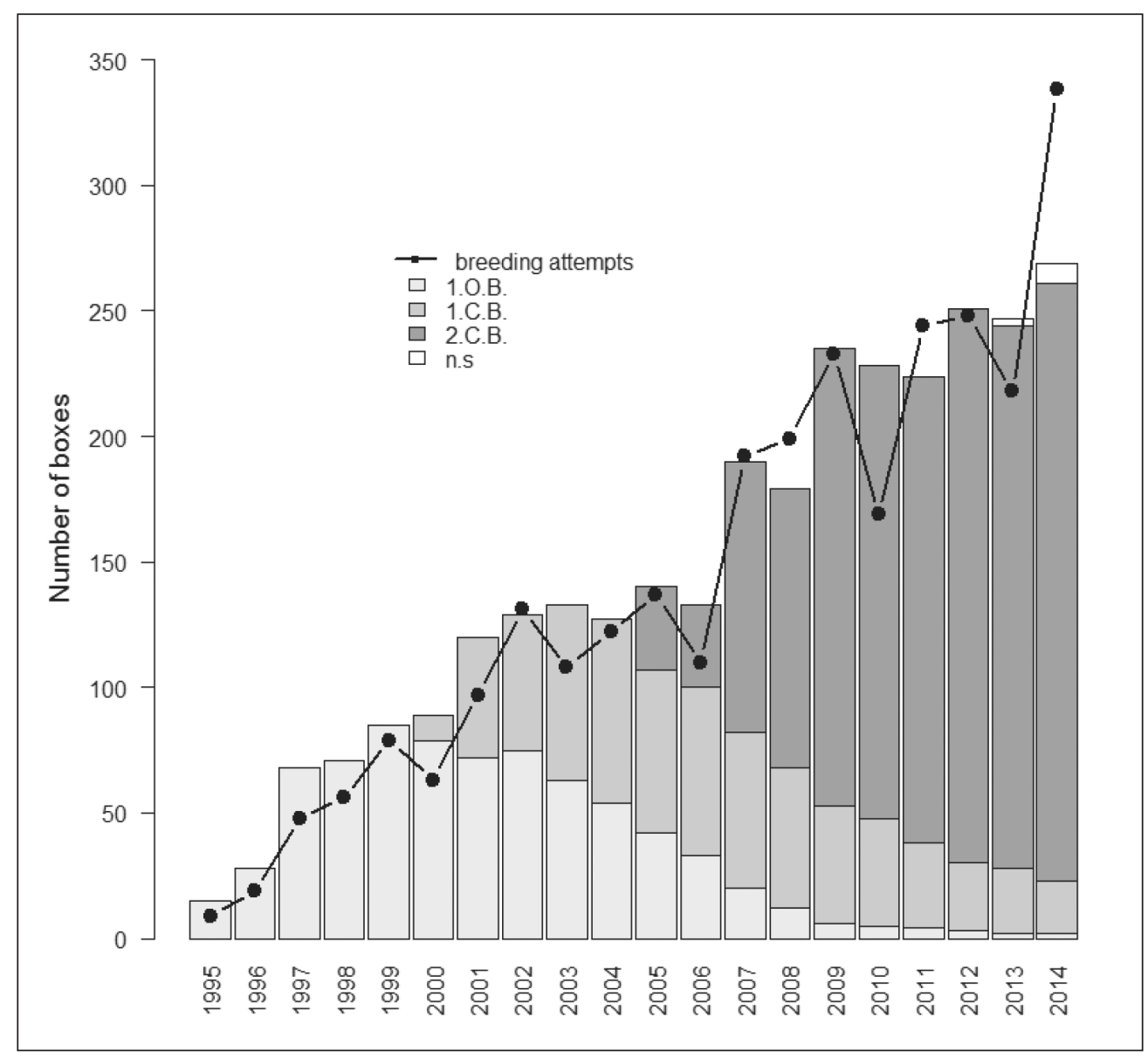

Figure 3. Cumulative number of nest-boxes, and the number of box designs available in each year of the study period. We have gradually shifted the proportions of nest-boxes to type 2.C.B: since 2006. Not specified (N.S.) are a small number of various other nest-box designs that have not been described in detail

3. ábra A kutatási területen található költőládák kumulatív száma a vizsgálati években, és az éveken belül elérhető különböző ládatípusok aránya. A nem definiált (N.S.) kategóriába olyan ládák tartoznak, amelyeket jelen cikkben nem részleteztünk

of artificial colonies. We also recorded the geographic coordinates of all solitary nesting attempts.

\section{Statistics}

To evaluate the potential differences in breeding success parameters between natural and artificial breeding sites, we only used the data of colonial pairs. Natural nest sites occurred in all studied artificial colonies, as a couple of hooded crows, or magpies built nests in the canopies of the trees holding the nest-box colonies. Since 2009, two rookeries were also established in the study area, that were used for breeding by Red-footed Falcons, thus we included the data deriving from these breeding attempts. To evaluate 


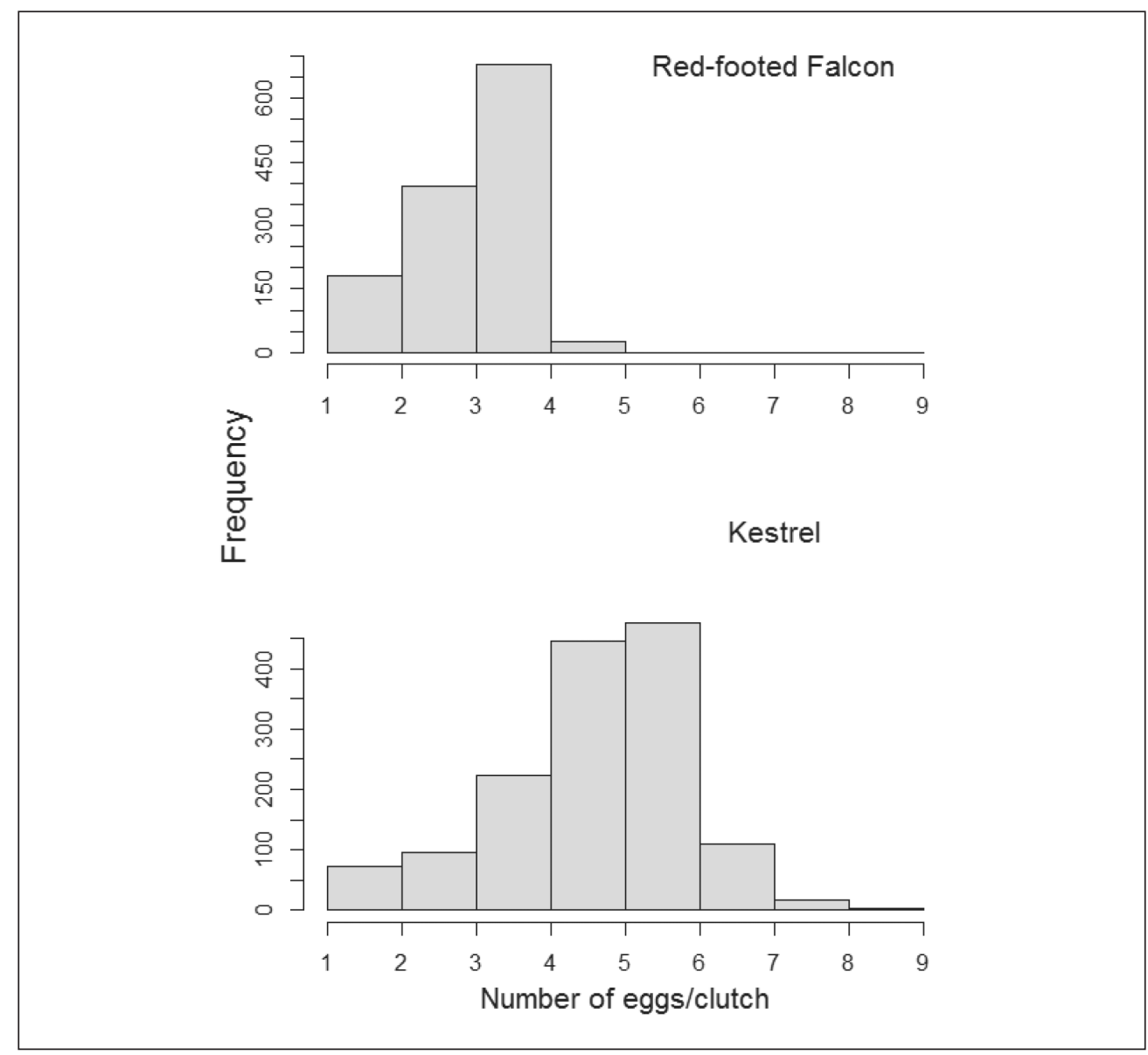

Figure 4. Clutch size histograms of Red-footed Falcons ( $n=1280$ clutches) and Kestrels $(n=1442$ clutches) during the study period

4. ábra Fészekalj méret hisztogramok a kék vércsék ( $n=1280$ fészekalj) és a vörös vércsék ( $n=1442$ fészekalj) esetén

\begin{tabular}{|c|c|c|c|c|c|c|c|c|c|}
\hline Species & $\begin{array}{l}\text { Number } \\
\text { of nesting } \\
\text { attempts }\end{array}$ & $\begin{array}{c}\text { Percentage } \\
\text { of solitary } \\
\text { attempts (\%) }\end{array}$ & $\stackrel{\oplus}{0}$ & نُ & نُ & $\begin{array}{l}\text { 웅 } \\
\stackrel{0}{0}\end{array}$ & 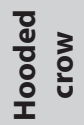 & $\begin{array}{l}\frac{0}{0} \\
\frac{0}{\pi} \\
\frac{\pi}{\Sigma}\end{array}$ & 这 \\
\hline Kestrel & 1626 & 11.6 & 395 & 319 & 686 & 53 & 37 & 111 & 25 \\
\hline Red-footed Falcon & 1432 & 9.1 & 224 & 148 & 654 & 206 & 31 & 145 & 24 \\
\hline Jackdaw & 702 & 1.1 & 1 & 366 & 333 & 0 & 0 & 0 & 2 \\
\hline Long-eared Owl & 217 & 15.7 & 53 & 13 & 59 & 18 & 7 & 65 & 2 \\
\hline
\end{tabular}

Table 2. Number of breeding attempts of the four most common species according to different breeding platforms observed during the 20 year study period

2. táblázat A négy leggyakoribb faj 20 év során megfigyelt költési kísérleteinek száma a különböző fészektípusokban 


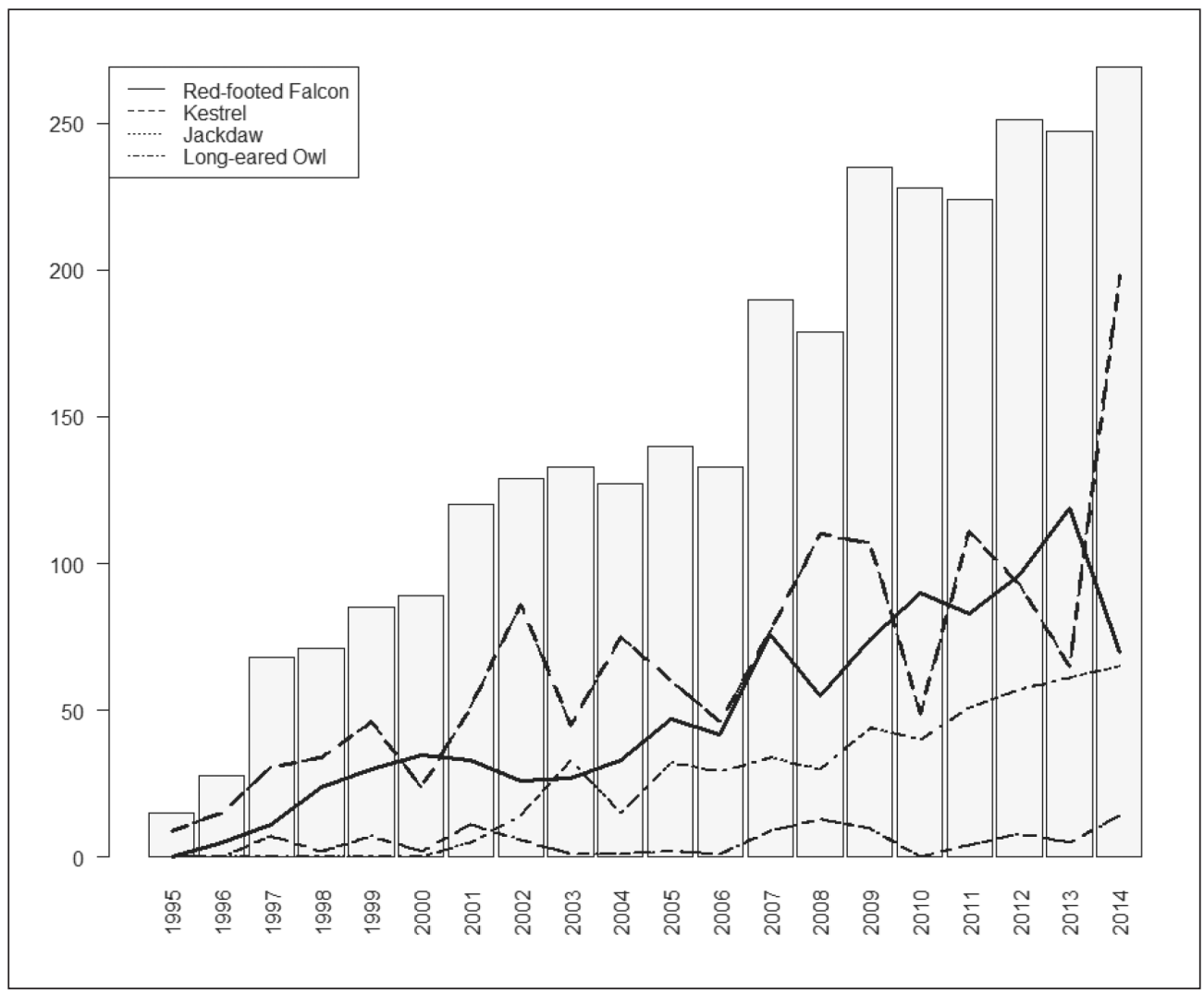

Figure 5. The cumulative number of nest-boxes (bars) and the number of breeding pairs (clutches with at least one egg) during the study period. Red-footed Falcons, Kestrels and Jackdaws show a significantly increasing trend (see Table 3), while Long-eared Owls remain relatively stable within the time framework presented. (The total number of breeding pairs may exceed the number of boxes available as the same boxes may be used by several species within a breeding season.) In 2014, the total number of Red-footed Falcons seemingly drops, however a relatively large proportion of the population used rookeries (natural nests, not depicted here), therefore the overall number of pairs increased within the study site

5. ábra Az összesen elérhető ládák száma (oszlopok) és a bennük költő különböző fajok párjainak (legalább egy tojást raktak a ládába) száma. Szignifikánsan nőtt (lásd. 3. táblázat) a kék vércse, vörös vércse és a csóka párok száma, míg az erdei fülesbaglyoké kevéssé változott az elmúlt 20 évben. (Egy adott évben a párok száma összesen magasabb lehet, mint az elérhető ládák száma, mert egy adott fészket a különböző fajok, vagy akár azonos faj különböző egyedei egymást követve használhatják egy költési perióduson belül). A kék vércsék esetén az utolsó évben látható csökkenést elsősorban az okozza, hogy ebben az évben a párok jelentős része a területen található vetési varjú telepeken költött

nest-box design effects we only used the data deriving from years (since 2006), when all nest-box types were available for the birds (Figure 3). As dependent variables we analysed clutch size (number of eggs/nest), fledging success (fledged nestlings/number of eggs) and nesting success (at least one fledged nestling/nest). We interpreted clutch size as a measure of the product of parental quality and investment and fledging success 
as the measure of parental quality and environmental effects.

In case of Kestrels, clutch size distribution and consequently other breeding performance parameters follow a relatively symmetrical distribution, however for Red-footed Falcons this is considerably different (Figure 4). Here, the distribution has a considerable skew, with $53 \%$ of all observed clutches containing 4 eggs. Modelling such distributions can be challenging with conventional general linear models (Faraway 2005), therefore avoid inferring results based on non-fitting linear models we used non-parametric tests in case of simple comparisons and Classification and Regression Trees (CART) to assess nest-box design effects on breeding performance (Breiman et al. 1984, De'ath 2002). The advantage of CART models is that they are less sensitive to the distribution of the dependent variables, and that they allow to map out multi-level effect hierarchy of explanatory variables (De'ath \& Fabricius 2000, Olden et al. 2008). To aid comparability, we applied these models for all species and we used nestbox type, year and type of breeding (colonial/ solitary) as explanatory variables for all models. We used R 3.2.0 for all statistical analyses carried out (R Core Team 2015).

\section{Results}

We recorded a total of 3977 breeding attempts of the four focus species between 1995 and 2015 (Table 2). Kestrels were the first to use the nest-boxes, a total of 9 pairs successfully fledged nestlings in the first year the artificial breeding sites were available (Figure 5). The first Red-footed Falcon pairs appeared in 1996, 2 years after the program started, followed by the first Longeared Owl pairs in 1997. The first Jackdaws only started breeding when 1.C.B. type boxes were first available in 2001 (Figure 5). The two falcon species and Jackdaws showed a significant increase in number of breeding pairs throughout the study period, while the number of Long-eared Owl pairs remained constant (Table 3). Descriptive statistics of breeding parameters of the four species are presented in Table 4. Albeit not apparent from the summary data, the two falcons have a considerable difference in the distribution of clutch size (Figure 4). In case of Red-footed Falcons, we found no difference in mean clutch size (Mann-Whitney U test: $\mathrm{U}=71512, \mathrm{p}=0.43$ ) and nesting success rate $\left(\chi^{2}\right.$ test: $\chi^{2}=0.261, \mathrm{df}=1, \mathrm{p}$-value $\left.=0.6\right)$ between colonial pairs breeding in artificial and natural nests. However, fledging success was significantly different (Mann-Whitney U test: $U=48826, p=0.02$ ), with higher fledging success in artificial nests. When we excluded closed box types from artificial nests (1.C.B. and 2.C.B.), and only compared 1.O.B. to natural nests, this difference was not apparent (Mann-Whitney U test: $U=1457.5, p=0.77$ ). In case of Kestrels clutch size was significantly higher in artificial nests (Mann-Whitney $U$ test: $U=30816, p<<0.001$, median difference=1 egg), while we found no difference in fledging success (Mann-Whitney $U$ test: $U=10354, p=0.12)$ or nesting success $\left(\chi^{2}\right.$ test: $\chi^{2}=2.98, \mathrm{df}=1, \mathrm{p}$-value $\left.=0.08\right)$. When only comparing 1.O.B. to natural nests, the difference in clutch size was no longer significant (Mann-Whitney $U$ test: $U=894, p=0.28$ ).

In case when only artificial nests were considered, clutch size of Red-footed Falcons was grouped by nest-box type in the second level, with 1.O.B and 2.C.B. having significantly higher number of eggs/ clutch compared to 1.C.B. in certain years (Figure 6) according to the CART analysis. However, clutch size was only influenced by 


\begin{tabular}{|l|c|c|c|c|c|}
\hline \multicolumn{1}{|c|}{ Species } & Effect of year & SE & t-value & p-value & $\mathbf{R}^{\mathbf{2}}$ \\
\hline Red-footed Falcon & 8.2 & 0.86 & 9.35 & $<0.0001$ & 0.83 \\
\hline Kestrel & 6.6 & 1.47 & 4.47 & $<0.0001$ & 0.49 \\
\hline Jackdaw & 4.05 & 0.41 & 9.83 & $<0.0001$ & 0.88 \\
\hline Long-eared Owl & 0.31 & 0.20 & 1.58 & 0.13 & 0.07 \\
\hline
\end{tabular}

Table 3. Linear regression effect summaries of time (year) on the number of breeding pairs of the 4 most common species at the study site. The number of Red-footed Falcons, Kestrels and Jackdaws show a significant mean increase, however the number of Long-eared Owl pairs remains constant over time

3.táblázat Az év, költés, költési kísérletek száma összefüggésre illesztett lineáris regressziós modellek becsült együtthatói és tesztjei, valamint R-négyzet értékei a négy leggyakoribb faj esetén. Az erdei fülesbagoly kivételével mindegyik faj költőállománya szignifikáns növekedést mutat az elmúlt 20 évben

\begin{tabular}{|l|c|c|c|c|c|c|}
\hline \multicolumn{7}{|c|}{ Clutch Size } \\
\hline & Mean & SE & SD & Median & Range & $\mathrm{n}$ \\
\hline Kestrel & 5.05 & 0.03 & 1.35 & 5 & $1-9$ & 1442 \\
\hline Red-footed Falcon & 3.38 & 0.02 & 0.88 & 4 & $1-5$ & 1280 \\
\hline Jackdaw & 4.35 & 0.05 & 1.32 & 5 & $1-7$ & 511 \\
\hline Long-eared Owl & 4.72 & 0.16 & 1.78 & 5 & $1-10$ & 132 \\
\hline \multicolumn{7}{|c|}{ Number of Fledged nestlings } \\
\hline & Mean & SE & SD & Median & Range & $\mathrm{n}$ \\
\hline Kestrel & 4.01 & 0.05 & 1.54 & 4 & $1-8$ & 1442 \\
\hline Red-footed Falcon & 2.76 & 0.04 & 1.05 & 3 & $1-5$ & 1280 \\
\hline Jackdaw & 2.44 & 0.06 & 1.22 & 2 & $1-6$ & 511 \\
\hline Long-eared Owl & 3.09 & 0.20 & 1.51 & 3 & $1-7$ & 132 \\
\hline & \multicolumn{7}{|c|}{ Fledging rate (\%) } & & \\
\hline & Mean & SE & SD & Median & Range & $\mathrm{n}$ \\
\hline Kestrel & 51.87 & 1.12 & 39.43 & 66.66 & $0-100$ & 1442 \\
\hline Red-footed Falcon & 48.77 & 1.29 & 42.29 & 50 & $0-100$ & 1280 \\
\hline Jackdaw & 34.94 & 1.55 & 32.77 & 33.33 & $0-100$ & 511 \\
\hline Long-eared Owl & 30.25 & 1.55 & 36.05 & 0 & $0-100$ & 132 \\
\hline
\end{tabular}

Table 4. Descriptive statistics of clutch size (maximum number of eggs), number of fledged nestlings (i.e. reproductive success) and fledging rate (i.e. ratio of successfully fledged nestlings/maximum number of eggs layed), for the 4 most common breeding species at the study site

4. táblázat A fészekaljméret, a repített fiókák száma, illetve a repítési siker (fiókák száma/fészekaljméret) leíró statisztikái a négy leggyakoribb költő faj esetén 
inter-annual differences in case of Kestrels, with similar between year patterns as in case of Red-footed Falcons (Figure 7). Fledging success of Red-footed Falcons was superior in 2.C.B. nest-boxes, regardless of seasonal effects (Figure 8), while only large (8.5$77 \%$ mean fledging rate) annual differences were observed in case of Kestrels (Figure 9).

\section{Discussion}

The colonization of the newly established artificial colonies by Kestrels, Long-eared
Owls and Red-footed Falcons was rapid. Kestrels were the first to breed in the 1.O.B. type boxes in the first year, followed by Red-footed Falcons and Long-eared Owls in the next year. This immediate and large scale acceptance of the man-made platforms probably indicates that nest-site shortage was a severely limiting factor in an area of high quality. The fact that Kestrels were the first to colonize is not surprising, this species was present as a breeder in solitary natural nests prior to the first nest-boxes were in place, albeit in small numbers. However, Red-footed Falcons were absent from the

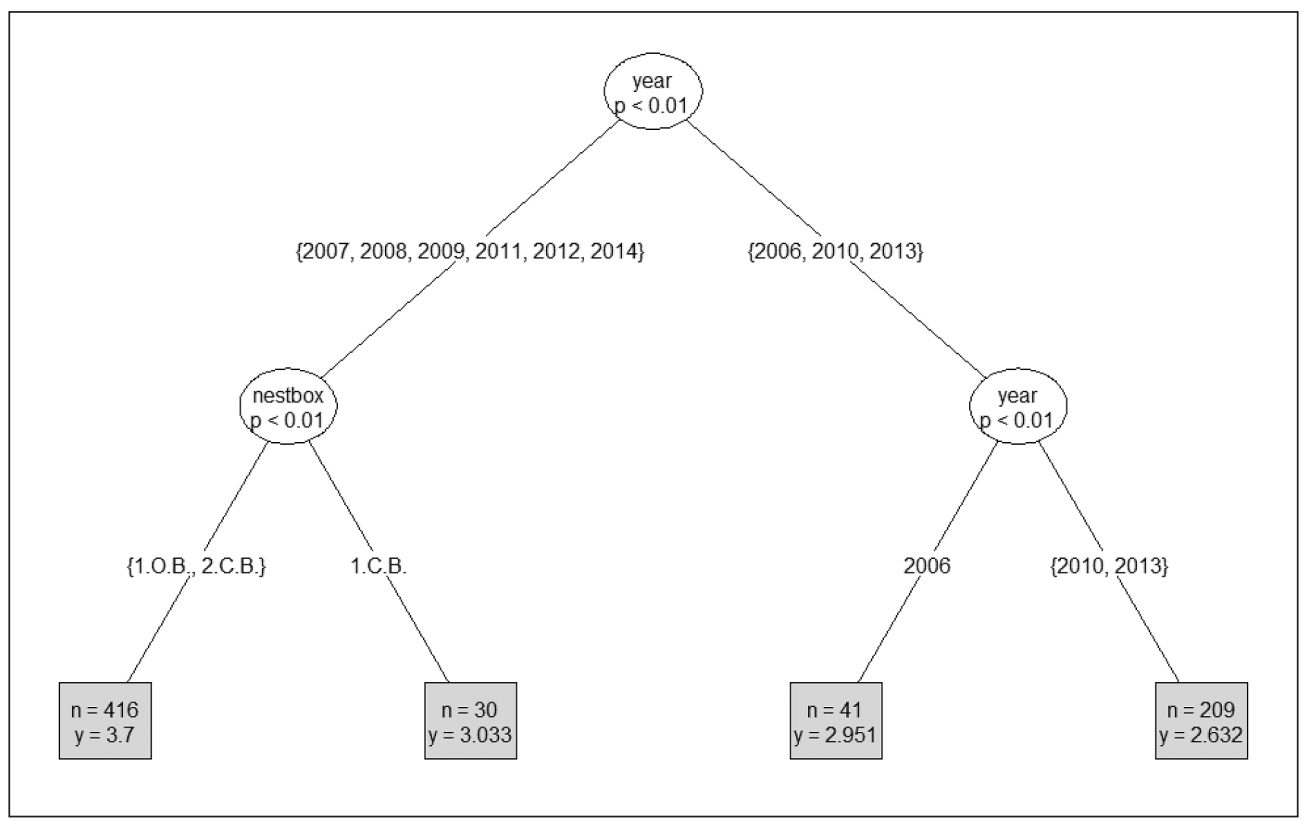

Figure 6. Regression tree on Red-footed Falcon clutch size grouped by years and nest-box type. Terminal nodes (grey boxes) show respective sample size ( $n$ ) and mean clutch size (y). In years when mean clutch size is larger (2007-2009, 2011, 2012 and 2014) nest-box type has a significant effect, with clutches in 1.C.B. being nearly an egg smaller on average compared to the other two box types. However, in low clutch size years (2006, 2010 and 2013) there is no apparent effect of nest-boxes

6. ábra Regressziós fa a kék vércsék fészekalj méretére az évek és a költőláda típus függvényében. A leveleken (szürke dobozok) az adott leágazáshoz tartozó mintaszámot (n) és a csoportátlagot ábrázoltuk (y). Azokban az években, amikor az átlagos fészekalj méret magas (2007-2009, 2011, 2012 és 2014), az 1.C.B. ládatípusban átlagosan majdnem egy tojással kisebb fészekaljat raknak a madarak. Azonban azokban az években, amikor az átlagos tojásszám alacsonyabb (2006, 2010 és 2013), a ládatípusnak nincs hatása 
area and practically from the surrounding region as well. It still remains unresolved how individuals find these resources. Perhaps non-breeding individuals, dispersing juveniles or passage migrants memorize potential future breeding sites, and return in the following seasons. Due to the relatively treeless landscape, the created artificial colonies stand out and are probably easily detectable for birds from larger distances. Another possibility is that falcons located and decided to breed in the colonies through heterospecific habitat copying (Parejo et al. 2005, Kivelä et al. 2014), using the cues provided by Kestrels (Sumasgutner et al. 2014). Jackdaws first appeared as in 2001, coinciding with the first breeding season when 1.C.B. type boxes were made available. These boxes are darker due to the relatively small entrance located asymmetrically on the front. Presumably, this design resembles the natural cavities, cliffs and corners of abandoned houses/ church towers typically used for nesting by Jackdaws (Soler \& Soler 1996, Henderson et al. 2000, Campobello et al. 2012). However, once a considerable number of pairs have established in the colonies, this species

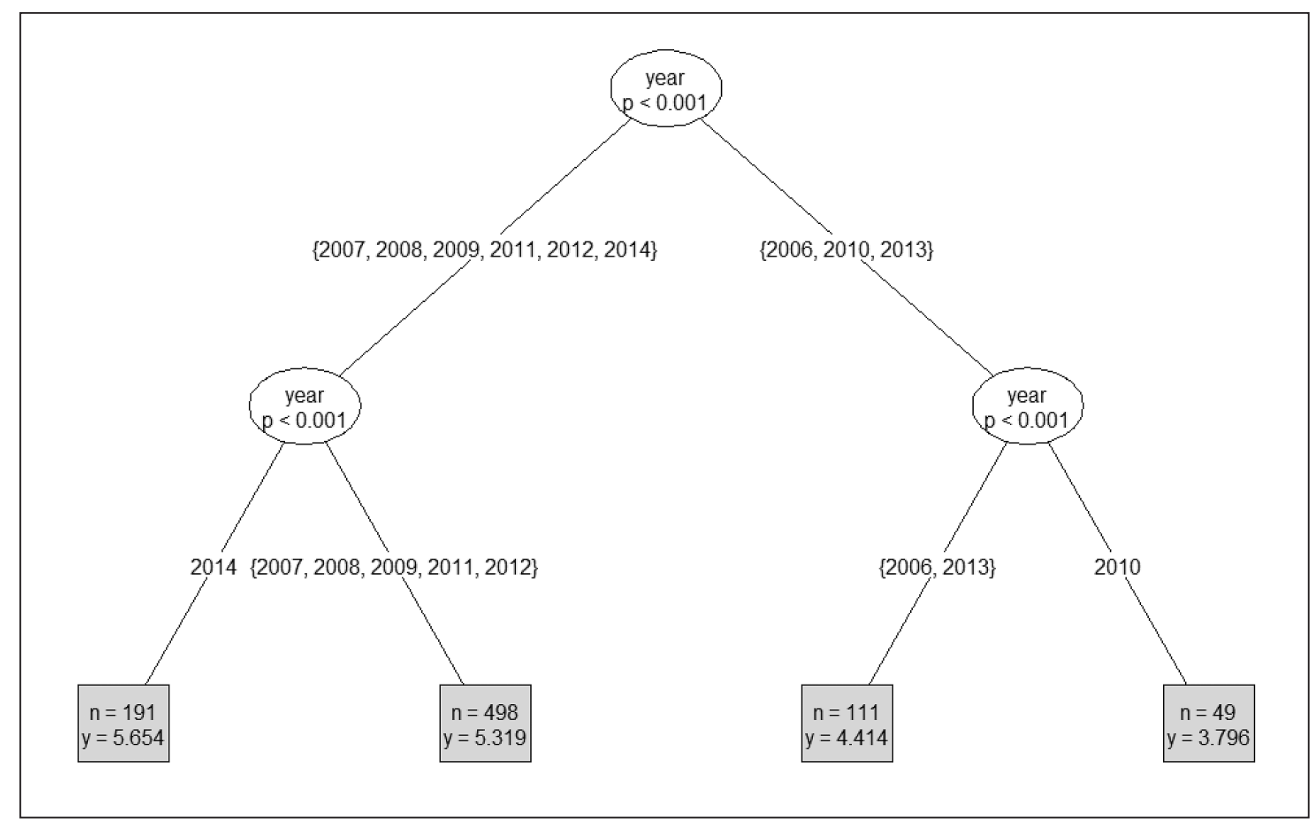

Figure 7. Regression tree on Kestrel clutch size grouped by years. Terminal nodes (grey boxes) show respective sample size $(\mathrm{n})$ and mean clutch size $(\mathrm{y})$. Nest-box type has no effect in neither years with high mean clutch sizes (2007-2009, 2011, 2012 and 2014) nor in low clutch size years (2006, 2010 and 2013). However, the inter-annual variation is remarkable, the differences in average clutch size can be up to nearly two eggs

7. ábra Regressziós fa a vörös vércsék fészekalj méretére az évek és a költőláda típus függvényében. A leveleken (szürke dobozok) az adott leágazáshoz tartozó mintaszámot (n) és a csoportátlagot ábrázoltuk (y). Sem azokban az években, amikor az átlagos fészekaljméret magas (2007-2009, 2011, 2012 és 2014), sem azokban, amikor alacsonyabb (2006, 2010 és 2013) nincs a láda típusának hatása. Azonban jelentős évek közötti eltérést lehet megfigyelni, majdnem két tojásnyi átlagos eltérés is lehet 


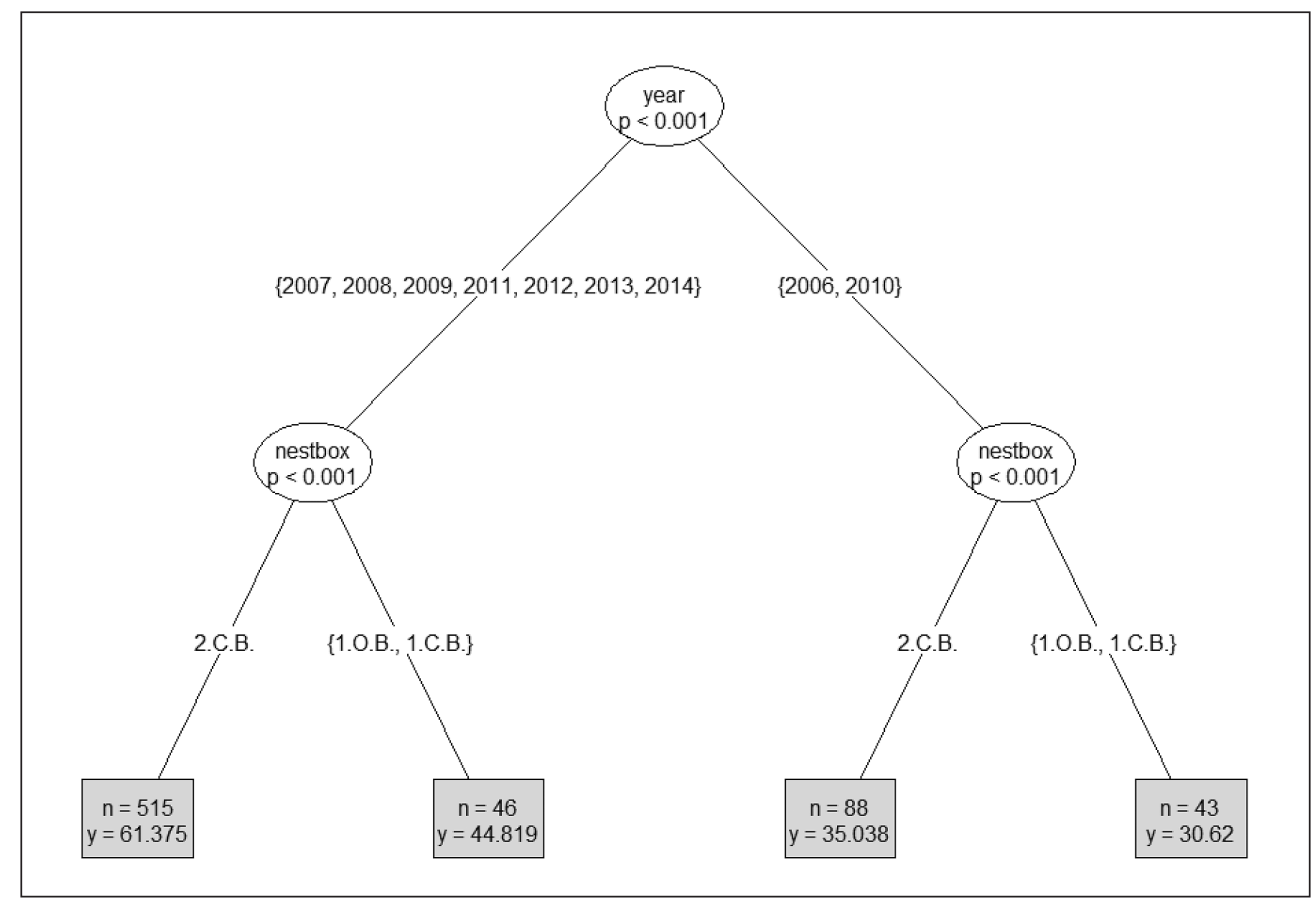

Figure 8. Regression tree on Red-footed Falcon fledging success (i.e. number of fledged nestling/ maximum number of eggs per clutch) grouped by years and nest-box type. Terminal nodes (grey boxes) show respective sample size ( $\mathrm{n}$ ) and mean clutch size (y). In years when fledging success is higher (2007-2009, 2011-2014) and in years when it is lower (2006 and 2010) nest-box type has a significant effect, with eggs in 2.C.B. having higher probability of becoming fledged nestlings

8. ábra Regressziós fa a kék vércse repítési sikerére az évek és a költőláda típus függvényében. A leveleken (szürke dobozok) az adott leágazáshoz tartozó mintaszámot (n) és a csoportátlagot ábrázoltuk (y). A repítési siker magasabb volt a 2.C.B. típusú ládában, mind azokban az években, amikor sikeresebbek voltak a madarak (2007-2009, 2011-2014), mind pedig azokban, amikor sikertelenebbek (2006 és 2010)

was able to switch to 2.C.B. nests in some occasions. Long-eared Owls appeared at the colonies together with Red-footed Falcons, however as opposed to the other three species, the number of breeding owl pairs remained near constant over the study period. This species is the most common nocturnal avian predator in the region, therefore it is unlikely that local population size is causing the observed pattern. Long-eared Owls are restricted territorial breeders, and may often breed in clusters (Rodriguez et al. 2006), thus intraspecific exclusion may have a smaller role in regulating breeding numbers at our colonies. Moreover, these birds are often the first to commence breeding at our study site (pers. obs.), thus the lack of empty potential platforms can be excluded. Owls are often mobbed by birds (Pavey \& Smyth 1998), and we have also observed such behaviour at our study site. Owls were mobbed by both falcon species quite often when flushed during nest-inspections, regardless of the presence of humans. We have also observed Red-footed Falcons harass incubating owls to the extent that the owls de- 


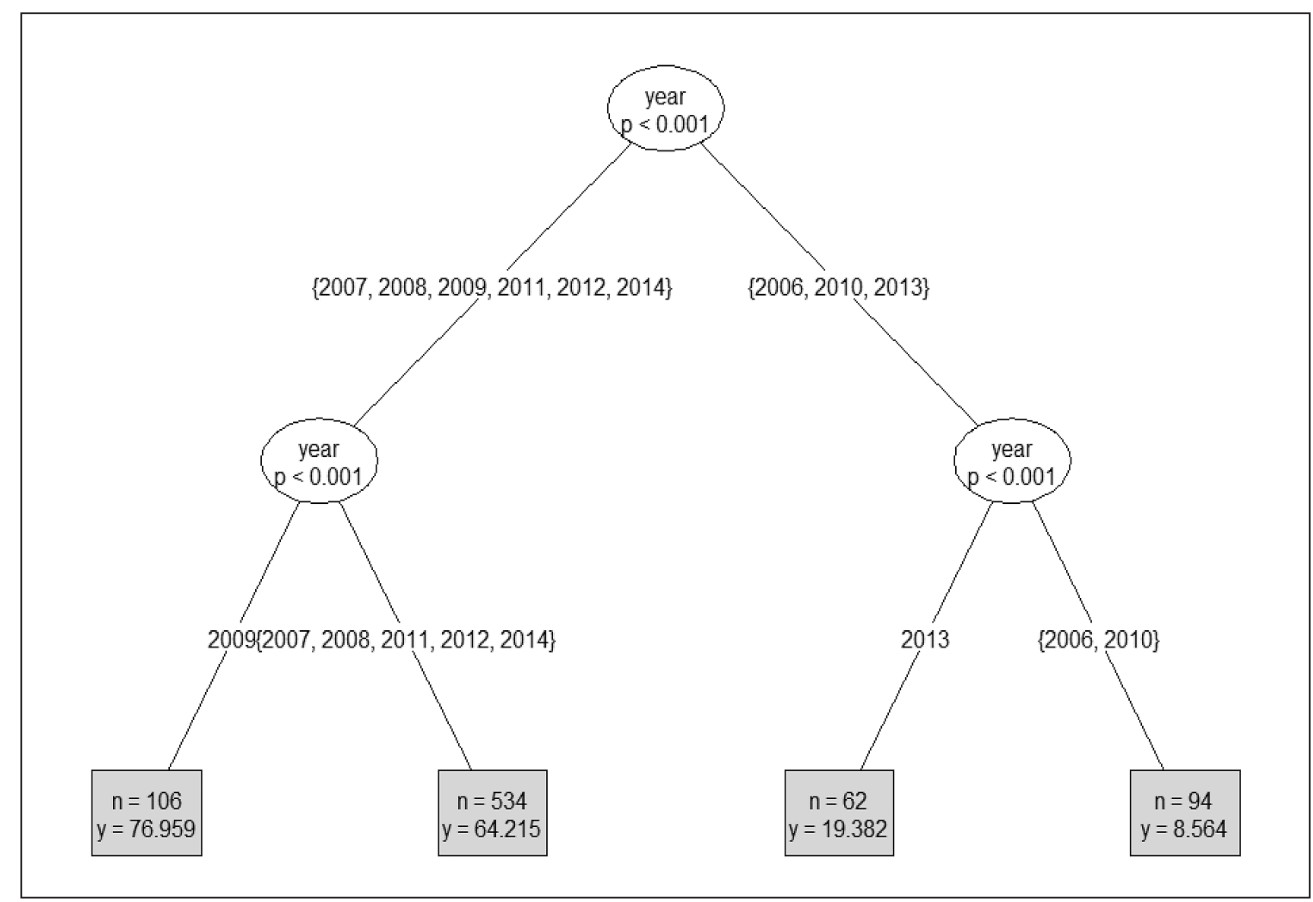

Figure 9. Regression tree on Kestrel fledging success (i.e. number of fledged nestling/maximum number of eggs per clutch) grouped by years. Terminal nodes (grey boxes) show respective sample size $(n)$ and mean clutch size (y). Nest-box type had no significant effect here, however there is a considerable difference between years as in the most successful year (2009) $77 \%$ of eggs reached became nestlings on average while in the worst years only $8.6 \%$ did

9. ábra Regressziós fa a kék vércsék repítési sikerére az évek és a költőláda típus függvényében. A leveleken (szürke dobozok) az adott leágazáshoz tartozó mintaszámot (n) és a csoportátlagot ábrázoltuk (y). Szemben a kék vércsékkel, a láda típusnak nincs csoportosító hatása, csak az évhatás határozta meg a repítési sikert. Azonban jelentős eltérések mutathatók ki évek között, míg a legjobb évben (2009) átlagosan 77\%-a a lerakott tojásoknak kikelt és kirepült, addig a legrosszabb években mindez csak 8,6\%

serted their clutch, leaving the box to be used by the harassing falcon pair. It may be plausible that despite their early breeding and potential to cluster into a confined area, the number of adverse interspecific interactions creates a pressure, that only the most competitive and/or resilient pairs can cope with, and that this pressure limits the number of pairs breeding in the studied colonies.

Concerning the effect of nest-type in colonies, we found that Red-footed Falcons laid the similar sized clutches in both artificial and natural nests however median fledging success is lower in natural stick nests. The former parameter reflects parental quality and investment into reproduction, indicating that breeding pairs probably did not differentiate among boxes in general and twig nests. The fact that fledging success was significantly lower in artificial nests, but when only considering open boxes, this difference disappeared probably indicates how closed boxes protect the clutches. Stick nests in our area are predominantly open nests, with 
the exception of newly built Magpie nests. These are seldom used by the falcons, typically 2-3 year old nests are occupied where the roof like structure is often missing. Thus, natural nests predominantly constitute open, roofless nests, while artificial nests are dominated by boxes with complete cover. The lack of significant difference in open boxes versus artificial nests therefore probably indicates how cover over clutches protects them from either predators or more likely, from adverse weather conditions. Stochastic extreme weather conditions are known to have a direct and detrimental effect on avian populations by causing direct mortality (Newton 2007). Heavy rainfall and hail from thunderstorms are not uncommon at our study site, and we have observed mass mortality effects of these previously. However, Kestrels had significantly larger clutch size in artificial closed nests, but had similar median fledging and overall nesting rates in natural nests. One would expect that cover over the clutches would have similar and general effects causing similar patterns across species. It is possible that Red-footed Falcons have different physiological coping mechanisms to extreme weather, or that roof cover is just a confounding effect masking true cause of the observed pattern.

When concentrating on nest-box types, in general only Red-footed Falcons were affected to a certain degree by the box-design, but both species were sensitive to inter-annual effects. The predominant prey for both species is the Common Vole (Microtus arvalis). Population density of this small mammal fluctuates multi-annually (Tkadlec \& Stenseth 2001) and can produce mass outbreaks (Jacob et al. 2014) as has happened in 2014. In a previous study, we have showed that despite the low variability in clutch size, Red-footed Falcons adjust their reproductory investment to vole abundance (Fehérvári et al. 2011). Kestrels are small mammal specialists with various adaptive responses to fluctuating prey abundance that entail immigration to high prey density areas and adjusting clutch size (Korpimäki \& Norrdahl 1991). Thus, the inter-annual effects in clutch size can be interpreted as adaptive responses to prey availability and to some degree to weather during the breeding period (Fehérvári et al. 2011). However, in years when mean clutch size was larger, Red-footed Falcons had significantly smaller clutches in 1.C.B., indicating that either parental quality and/or investment was different in case of pairs breeding in these boxes. These boxes may have different thermal regimes, light-levels within and a narrow view-point from the inside for incubating birds. Moreover, Jackdaws that predominantly prefer these boxes often build stick nests within, further decreasing light and visibility. It is possible that Red-footed Falcons generally avoid and thus, only less competitive pairs utilize these boxes, due to these factors. Fledging success was also lower here, together with 1.O.B., in both high and low success rate years compared to that in 2.C.B. nests. The lack of difference in clutch size between 1.O.B. and 2.C.B., while a significant deviation in mean fledging rate may indicate, that the falcons showed no avoidance to open boxes, but had lower success due to the lack of cover. On the other hand fledging success was also lower for 1.C.B. compared to 2.C.B. while both boxes provide cover. The indication of lower parental quality/investment in 1.C.B. boxes based on clutch size may also be reflected in fledging success. Therefore, the observed pattern in the two box types may derive from alternative processes resulting in similar reproductive output.

Our results demonstrate that multi-species nest-box colonies may be extremely success- 
ful in aiding the colonization of novel areas by several species. Seemingly, the falcon species breeding in these artificial colonies have somewhat different breeding success patterns compared to natural nests, however they are not inferior to these. Generalizing results obtained at these colonies is possible to birds breeding in natural nests, providing future statistical analyses incorporate nest-type effects. However, it is possible that individuals breeding at these sites experience factors not present at natural breeding sites. For instance, Red-footed Falcons have to cope with a dynamic within colony nest location pattern that changes each year in rookeries (Purger \& Tepavčević 1999), while the location of nest-boxes remains constant over a long time period. Furthermore, closed boxes restrict field of view from the birds' perspective compared to open rook nests. These may alter social interaction patterns, and thus birds may have different adaptive responses to these as in rookeries. From a conservation perspective, as tool, nest-boxes in this environment are successful and have to be propagated. However, mid-to long term research

\section{References}

Ángyán, J., Tardy, J. \& Vajnáné, M. A. 2002. Védett és érzékeny természeti területek mezőgazdálkodásának alapjai [Agriculture for Environmentally Protected and Sensitive Areas]. - Mezőgazda Kiadó, Budapest, pp. 368 (in Hungarian)

Bagyura, J. \& Palatitz, P. 2004. Fajmegőrzési tervek (Falco vespertinus) [Species Conservation Plans, Red-footed Falcon (Falco vespertinus)]. - Ministry of Environment and Water, Budapest, pp. 39 (in Hungarian)

Báldi, A., Batáry, P. \& Erdős, S. 2005. Effects of grazing intensity on bird assemblages and populations of Hungarian grasslands. - Agriculture, Ecosystems \& Environment 108(3): 251-263. DOI: 10.1016/j.agee.2005.02.006

Bortolotti, G. R. 1994. Effect of nest-box size on nestsite preference and reproduction in American Kestrels. - Journal of Raptor Research 28(3): 127133. and conservation efforts have to concentrate on preserving, managing and if possible further increasing the number of rookeries to ensure sustainability of the already existing population.

\section{Acknowledgements}

We express our gratitude to all volunteers whom contributed to field work and data collection. Of these we especially thank the assistance of Antal Baranyai, Ferenc Lencse and Gábor Tóth. We are grateful to the leaders (Gyula Molnár, Péter Lovászi) of the Csongrád County local group of MME/ BirdLife Hungary for funding and supporting the project in the early period with equipment. We also thank Zoltán Petrovics "Sáros" for developing the 2.C.B. nest-box type and providing us with the invaluable experience he has in constructing man-made nests. This project was funded by LIFE Nature (LIFE05/NAT/HU/000122, LIFE11/ NAT/HU/000926) and HU-SRB IPA CBC (HU-SRB 0901/122/120) projects.

Breiman, L., Friedman, J., Olshen, R. A. \& Stone, C. J. 1984. Classification and decision trees. - Belmont, Wadsworth CA, pp. 356

Bux, M., Giglio, G. \& Gustin, M. 2008. Nest box provision for Lesser Kestrel Falco naumanni populations in the Apulia region of southern Italy. - Conservation Evidence 5: 58-61.

Campobello, D., Sarà, M. \& Hare, J. F. 2012. Under my wing: Lesser Kestrels and Jackdaws derive reciprocal benefits in mixed-species colonies. - Behavioral Ecology 23(2): 425-433. DOI: 10.1093/ beheco/arr207

Catry, I., Franco, A. M., Rocha, P., Alcazar, R., Reis, S., Cordeiro, A., Ventim, R., Teodósio, J. \& Moreira, F. 2013. Foraging habitat quality constrains effectiveness of artificial nest-site provisioning in reversing population declines in a colonial cavity nester. - PloS One 8(3): e58320. DOI: 10.1371/ journal.pone. 0058320 
Csörgey, T. 1908. A M.O.K. ezévi müködése a gyakorlati madárvédelem terén [Annual bird conservation report of the M.O.K.]. - Aquila 15: 302-305. (in Hungarian and German)

De'ath, G. 2002. Multivariate regression trees: a new technique for modeling species-environment relationships. - Ecology 83(4): 1105-1117. DOI: 10.1890/0012-9658(2002)083[1105:MRTANT] 2.0.CO;2

De'ath, G. \& Fabricius, K. E. 2000. Classification and regression trees: a powerful yet simple technique for ecological data analysis. - Ecology 81: 3178-3192. DOI: $10.1890 / 0012-9658(2000) 081$ [3178:CARTA $\mathrm{P}] 2.0 . \mathrm{CO} ; 2$

Donald, P. F., Pisano, G., Rayment, M. D. \& Pain, D. J. 2002. The Common Agricultural Policy, EU enlargement and the conservation of Europe's farmland birds. - Agriculture, Ecosystems \& Environment 89(3): 167-182. DOI: 10.1016/S0167-8809(01)00244-4

Faraway, J. J. 2005. Extending the linear model with R: generalized linear, mixed effects and nonparametric regression models. - CRC Press, pp. 331

Fargallo, J. A., Blanco, G., Potti, J. \& Viñuela, J. 2001. Nestbox provisioning in a rural population of Eurasian Kestrels: breeding performance, nest predation and parasitism. - Bird Study 48(2): 236-244.

Fehérvári, P., Harnos, A., Solt, Sz. \& Palatitz, P. 2009. Modeling habitat selection of the Red-footed Falcon (Falco vespertinus): A possible explanation of recent changes in breeding range within Hungary. - Applied Ecology and Environment 7(1): 59-69.

Fehérvári, P., Lázár, B., Palatitz, P., Solt, Sz., Kotymán, L. \& Harnos, A. 2011. Az időjárás hatásai a kék vércse (Falco vespertinus) fészekalj-méretére [The effect of weather on Red-footed Falcon (Falco vespertinus) clutch size]. - "Klíma 21" füzetek (65): 53-64. (in Hungarian)

Fehérvári, P., Solt, Sz., Palatitz, P., Barna, K., Ágoston, A., Gergely, J., Nagy, A., Nagy, K. \& Harnos, A. 2012. Allocating active conservation measures using species distribution models: a case study of Red-footed Falcon breeding site management in the Carpathian Basin. - Animal Conservation 15(6): 648-657. DOI: 10.1111/j.1469-1795.2012.00559.x

Fehérvári, P., Piross, I. S., Soltész, Z., Kotymán, L., Solt, Sz. Horváth, É. \& Palatitz, P. 2015. Species specific effect of nest-box cleaning on settlement decisions in an artificial colony system. - Ornis Hungarica 23(1): 66-76. DOI: 10.1515/orhu-2015-0006

Franco, A., Marques, J. T. \& Sutherland, W. J. 2005. Is nest-site availability limiting Lesser Kestrel populations? A multiple scale approach. - Ibis 147(4): 657-666. DOI: 10.1111/j.1474-919x.2005.00437.x

Gottschalk, T. K., Ekschmitt, K. \& Wolters, V. 2011. Efficient placement of nest boxes for the Little Owl
(Athene noctua). - Journal of Raptor Research 45(1): 1-14. DOI: 10.3356/JRR-09-11.1

Hamerstrom, F., Hamerstrom, F. N. \& Hart, J. 1973. Nest boxes: an effective management tool for Kestrels. - The Journal of Wildlife Management 37(3): 400-403.

Henderson, I., Hart, P. \& Burke, T. 2000. Strict monogamy in a semi-colonial passerine: the Jackdaw Corvus monedula. - Journal of Avian Biology 31(2): 177-182. DOI: 10.1034/j.1600048X.2000.310209.x

Horváth, É., Solt, Sz., Kotymán, L., Palatitz, P., Piross, I. S. \& Fehérvári, P. 2015. Provisioning nest material for Rooks, a potential tool for conservation management - Ornis Hungarica 23(1): 22-31. DOI: 10.1515/orhu-2015-0002

Jacob, J., Manson, P., Barfknecht, R. \& Fredricks, T. 2014. Common Vole (Microtus arvalis) ecology and management: implications for risk assessment of plant protection products. - Pest Management Science 70(6): 869-878. DOI: 10.1002/ps.3695

Katzner, T., Robertson, S., Robertson, B., Klucsarits, J., McCarty, K. \& Bildstein, K. L. 2005. Results from a long-term nest-box program for American Kestrels: implications for improved population monitoring and conservation. - Journal of Field Ornithology 76(3): 217-226. DOI: 10.1648/02738570-76.3.217

Keve, A. \& Szijj, J. 1957. Distribution, biologie et alimentation du Facon kobez Falco vespertinus L. en Hongrie [Distribution, biology and allimentation of Red-footed Falcons in Hungary]. - Alauda 25(1): 1-23. (in French)

Kiss, O., Elek, Z. \& Moskát, C. 2014. High breeding performance of European Rollers Coracias garrulus in heterogeneous farmland habitat in southern Hungary. - Bird Study 61(4): 496-505. DOI: 10.1080/00063657.2014.969191

Kivelä, S. M., Seppänen, J-T., Ovaskainen, O., Doligez, B., Gustafsson, L., Mönkkönen, M. \& Forsman, J. T. 2014. The past and the present in decision-making: the use of conspecific and heterospecific cues in nest site selection. - Ecology 95(12): 34283439. DOI: 10.1890/13-2103.1

Korpimäki, E. \& Norrdahl, K. 1991. Numerical and functional responses of Kestrels, Short-eared Owls, and Long-eared Owls to vole densities. - Ecology 72(3): 814-826. DOI: 10.2307/1940584

Kotymán, L. 2001. A vörös vércse (Falco tinnunculus) és a kék vércse (Falco vespertinus) telepítésének gyakorlata a Vásárhelyi-pusztán [Establishing artificial colonies of Kestrels (Falco tinnunculus) and Red-footed Falcons (Falco vespertinus) in the Vásárhelyi-puszta]. - Túzok 6: 120-129. (in Hungarian) 
Lambrechts, M. M., Wiebe, K. L., Sunde, P., Solonen, T., Sergio, F., Roulin, A., Møller, A. P., López, B. C., Fargallo, J. A., Exo, K-M., Dell'Omo, G., Costantini, D., Charter, M., Butler, M. W., Bortolotti, G. R., Arlettaz, R. \& Korpimäki, E. 2012. Nest box design for the study of diurnal raptors and owls is still an overlooked point in ecological, evolutionary and conservation studies: a review. - Journal of Ornithology 153(1): 23-34. DOI: 10.1007/s10336-011-0720-3

Mainwaring, M. C. 2015. The use of man-made structures as nesting sites by birds: A review of the costs and benefits. - Journal for Nature Conservation 25: 17-22. DOI: 10.1016/j.jnc.2015.02.007

Molnár, G. 2000. A kék vércse, a vörös vércse és az erdei fülesbagoly mesterséges telepítésének eredményei a Dél-Alföldön [The breeding of the Red-footed Falcon (Falco vespertinus), Kestrel (Falco tinnunculus) and Long-eared Owl (Asio otus) in artificial nest boxes in the Dél-Alföld region]. - Ornis Hungarica 10: 93-98. (in Hungarian with English Summary)

Molnár, G., Bíró, M., Virók, V. \& Kotymán, L. 2012. A Vásárhelyi-puszta növényzete és növényzeti változásai az elmúlt 10 évben [Flora and changes in vegetation of the past 10 years in the Vásárhelyi-puszta]. - Cirsicum 7: 57-76. (in Hungarian)

Molnár, G. \& Tajti, L. 2007. Pusztaszeri Tájvédelmi Körzet. - In: Tardy, J. (ed.) A magyarországi vadvizek világa - Hazánk ramsari területei [The world of Hungarian wetlands]. - Alexandra Kiadó, Pécs, Hungary, pp. 416 (in Hungarian)

Newton, I. 2007. Weather-related mass-mortality events in migrants. - Ibis 149(3): 453-467. DOI: 10.1111/j.1474-919X.2007.00704.x

Olden, J. D., Lawler, J. J. \& Poff, N. L. 2008. Machine learning methods without tears: a primer for ecologists. - Quarterly Review of Biology 83(2): 171193. DOI: $10.1086 / 587826$

Palatitz, P., Fehérvári, P., Solt, Sz. \& Barov, B. 2009. European Species Action Plan for the Red-footed Falcon Falco vespertinus Linnaeus, 1766. - European Comission, pp. 49

Palatitz, P., Fehérvári, P., Solt, Sz., Kotymán, L., Neidert, D. \& Harnos, A. 2011. Exploratory analyses of foraging habitat selection of the Red-footed Falcon (Falco vespertinus). - Acta Zoologica Academiae Scientiarum Hungaricae 57(3): 255-268.

Palatitz, P., Fehérvári, P., Solt, Sz. \& Horváth, É. 2015. Breeding population trends and pre-migration roost site survey of the Red-footed Falcon in Hungary. - Ornis Hungarica 23(1): 77-93. DOI: 10.1515/ orhu-2015-0007

Parejo, D., Danchin, E. \& Avilés, J. M. 2005. The heterospecific habitat copying hypothesis: can competitors indicate habitat quality? - Behavioral Ecology 16(1): 96-105. DOI: 10.1093/beheco/arh136
Pavey, C. R. \& Smyth, A. K. 1998. Effects of avian mobbing on roost use and diet of Powerful Owls, Ninox strenua. - Animal Behaviour 55(2): 313318. DOI: $10.1006 /$ anbe.1997.0633

Purger, J. J. \& Tepavčević, A. 1999. Pattern analysis of Red-footed Falcon (Falco vespertinus) nests in the Rook (Corvus frugilegus) colony near Torda (Voivodina, Yugoslavia), using fuzzy correspondences and entropy. - Ecological Modelling 117(1): 91-97. DOI: 10.1016/S0304-3800(99)00012-5

R Core Team 2015. R: A language and environment for statistical computing. - R Foundation for Statistical Computing Vienna, Austria, Retrieved from http:// www.R-project.org/

Rodriguez, A., Garcia, A. M., Cervera, F. \& Palacios, V. 2006. Landscape and anti-predation determinants of nest-site selection, nest distribution and productivity in a Mediterranean population of Longeared Owls Asio otus. - Ibis 148(1): 133-145. DOI: 10.1111/j.1474-919X.2006.00492.x

Soler, M. \& Soler, J. J. 1996. Effects of experimental food provisioning on reproduction in the Jackdaw Corvus monedula, a semi-colonial species. - Ibis 138(3): 377-383. DOI: 10.1111/j.1474-919X.1996. tb08054.x

Sterbetz, I. 1959. A hódmezővásárhelyi szikesek madárvilága [Birdlife of the alkaline grasslands around Hódmezővásárhely]. - Aquila 65: 189-207. (in Hungarian)

Sterbetz, I. 1975. A Kardoskúti Természetvédelmi Terület madárvilága 1952 és 1973 időközében [Birdlife of Kardoskút Nature Protection Area between 1952-1973]. - Aquila 80/81: 91-120. (in Hungarian)

Sumasgutner, P., Vasko, V., Varjonen, R. \& Korpimäki, E. 2014. Public information revealed by pellets in nest sites is more important than ecto-parasite avoidance in the settlement decisions of Eurasian Kestrels. - Behavioral Ecology and Sociobiology 68(12): 2023-2034. DOI: 10.1007/s00265-0141808-6

Tkadlec, E. \& Stenseth, N. C. 2001. A new geographical gradient in vole population dynamics. - Proceedings of the Royal Society of London Series B: Biological Sciences 268(1476): 1547. DOI: 10.1098/ rspb.2001.1694

Tóth, I. 1995. Békés megyei ragadozómadár-állomány helyzete és változása [The status and changes in raptor populations of Békés County]. - MME Kiadvány, pp. 55 (in Hungarian)

Vajda, Z. 1992. Vércse-fajok megtelepítése mesterséges fészkekkel [Using nest-boxes to establish small falcon breeding populations]. - Himantopus 1: 7. (in Hungarian) 